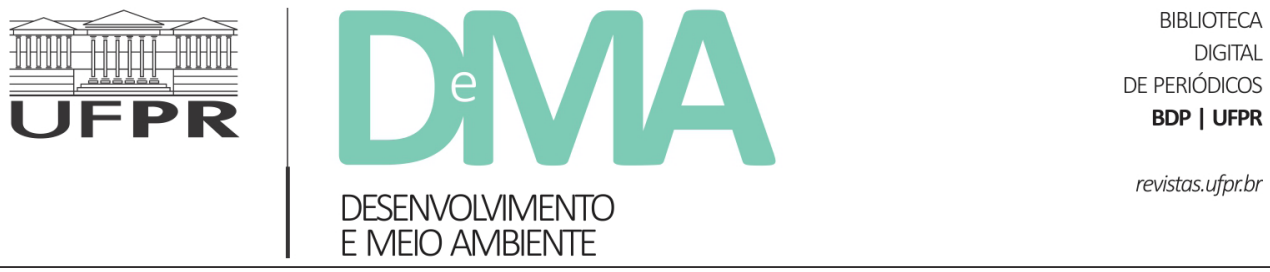

\title{
A Laboratory without walls: biodiversity education in nutrition training using a garden-based learning method
}

\section{Um laboratório a céu aberto: educação para biodiversidade na formação em nutrição com uso do método da aprendizagem baseada em hortas}

Ana Carolina Costa Campos MOTA ${ }^{1}$, Ana Francisca Teixeira GOMES ${ }^{1}$, Laura Brito PORCIÚNCULA ${ }^{1}$, Viviany Moura CHAVES ${ }^{1}$, Adriana Monteiro de ALMEIDA ${ }^{1}$, Thiago Perez JORGE ${ }^{1}$, Michelle Cristine Medeiros $\mathrm{JACOB}^{1 *}$

${ }^{1}$ Universidade Federal do Rio Grande do Norte (UFRN), Natal, RN, Brasil.

*E-mail of contact: michellejacob@ufrn.edu.br

Article received on December 28, 2019, final version accepted on September 29, 2020, published on May 27, 2021.

ABSTRACT: In the field of nutrition, there is a growing demand for human resources to have the capacity to promote sustainable diets. Nutrition science, however, faces challenges that limit its capacity to build a proper workforce to respond to this demand. The lack of knowledge about biodiversity, central to sustainable diets, is one of them. This deficiency is partly caused by fragmented traditions of thought - social, environmental, and biological - in the area. We argue that biodiversity education with the support of the Garden-Based Learning (GBL) method can help in approaching this limitation. The study is an experience report of professors and students involved in a garden laboratory in the nutrition program at a public university in northeastern Brazil. We describe the laboratory's history, design, and our working methodology focused on the theme of Unconventional Food Plants. We present examples of the application of the method from experiences with plants studied in 2019. The use of the GBL method provided opportunities for actions to address the challenges presented by biodiversity education: discussion of professors' capacities, the institutionalization of the laboratory, the inclusion of a course on Sustainable food systems in the curriculum, work with a multi-professional team, strengthening community ties and adapting tools for cross-cultural contexts. In these actions, we systematically approach knowledge about taxonomy, phylogeny, ecosystems, and cultural diversity. The scarcity of literature on the subject limited our capacity to analyze our work within a frame of reference. We hope our report can encourage similar initiatives by guiding the use of the method. In future research, we intend to measure the impact of these strategies on the development of competencies for working with biodiversity in nutrition training.

Keywords: food plants; food and nutrition security; higher education; problem-based learning.

Desenvolv. e Meio Ambiente usa uma Licença Creative Commons - Atribuição-NãoComercial-SemDerivações 4.0 Internacional 226 
RESUMO: No campo da nutrição, há uma demanda crescente por recursos humanos com capacidade para promover dietas sustentáveis. A ciência da nutrição, no entanto, enfrenta desafios que limitam sua capacidade de criar uma força de trabalho adequada para responder a essa demanda. A falta de conhecimento sobre biodiversidade, central para as dietas sustentáveis, é uma delas. Essa deficiência é parcialmente causada por tradições fragmentadas de pensamento - social, ambiental e biológico - na área. Argumentamos que a educação para biodiversidade, com o apoio do método de Aprendizagem Baseada em Hortas (ABH), podem ajudar a abordar esse limite. $\mathrm{O}$ estudo é um relato de experiência de professores e alunos envolvidos em um laboratório horta em um curso de nutrição de uma universidade pública do nordeste do Brasil. Descrevemos o histórico, o design e a metodologia de trabalho do laboratório, focada no tema de Plantas Alimentícias Não Convencionais. Apresentamos exemplos da aplicação do método a partir de experiências com plantas estudadas em 2019. O uso do método ABH proporcionou oportunidades para ação objetivando o enfrentamento dos desafios apresentados pela educação para biodiversidade: discussão sobre a formação dos professores, institucionalização do laboratório, inclusão de um curso sobre Sistemas alimentares sustentáveis no currículo, trabalho com uma equipe multiprofissional, fortalecimento dos laços comunitários e adaptação de ferramentas para contextos transculturais. Nessas ações, abordamos sistematicamente o conhecimento sobre taxonomia, filogenia, ecossistemas e diversidade cultural. A escassez de literatura sobre o assunto limitou nossa capacidade de analisar nosso trabalho dentro de um quadro prévio de referências. Esperamos que nosso relato possa incentivar iniciativas semelhantes, orientando o uso do método. Em pesquisas futuras, pretendemos medir o impacto dessas estratégias no desenvolvimento de competências para trabalho com a biodiversidade na formação em nutrição.

Palavras-chave: plantas alimentícias; segurança alimentar e nutricional; educação superior; aprendizagem baseada em problemas.

\section{Introduction}

Recognized as one of the largest holders of biological diversity in the world, Brazil boasts a flora that represents over $20 \%$ of the total species on the planet (Martinelli \& Moraes, 2013). In addition to its ecological and economic importance, about $10 \%$ of these plants are food, having the potential to diversify menus and generate new production chains, with impacts on human, environmental and economic health (Andrade-Cetto \& Heinrich, 2005; Kinupp \& Barros, 2008; Kinupp \& Lorenzi, 2014; UN, 2015). The current problem is that much of the human diet, which used to consist of a wide variety of plants, has gradually shifted to intake of ultra-processed foods and, consequently, a limited number of species (Lachat et al., 2018)
In recent years, food biodiversity has been neglected worldwide, especially with the transformations of the globalized food system. In Brazil, since Valdely Kinupp's classic work in 2014, we have conventionally referred to this unexplored biodiversity as Unconventional Food Plants (UFP) (Viana et al., 2015). UFP are plants that are characterized by their unconventionality concerning a particular group or geographical cut. They can be native or exotic, cultivated, or spontaneous and frequently unavailable for sale in supermarkets or conventional supply chains (Brasil, 2010; Oliveira et al., 2013; Kinupp \& Lorenzi, 2014; Viana et al., 2015; Narciso et al., 2017).

Despite their potential to collaborate with food and nutrition security, UFP still represents underexploited food biodiversity. Food and Agriculture Organization of the United Nations (FAO) estimates 
that around 30,000 plant species worldwide are edible. However, more than half of the energy currently consumed globally comes from only four crops: rice, potatoes, wheat, and corn (FAO, 2010). This information deserves attention, as dietary diversity is related to its nutritional adequacy and environmental health (Lachat et al., 2018). Thus, stimulating UFP consumption, besides being a protective strategy for biodiversity, enhances the ingestion of a wide range of nutrients and bioactive compounds that contain antioxidant substances with various beneficial properties to the human body (Ipes-Food, 2017). Based on this, how can we explain the low utilization of Brazilian food biodiversity?

The dynamics of the globalized agri-food system - productive profile, the concentration of distribution centers, and dietary patterns - could explain this tendency of homogenization (Ipes-Food, 2016). In addition to it, we highlight two factors. The first factor concerns a more general symptom called botanical blindness by Wandersee \& Schussler (2001). One of the characteristics of botanical blindness is the people's inability to recognize plants, their importance in the biosphere, and our daily lives. With the increasingly scarce contact of urban populations with plant resources, this is a widespread symptom (Salatino \& Buckeridge, 2016). The second relates to the professional education of those who work with food, especially nutritionists. Among the assigned roles for registered dietitians and dietitians, the "Academy of Nutrition and Dietetics" provides for the promotion of understanding of issues involving food and nutrition security, agricultural production, and sustainable food environment. One of the competencies listed for this professional, to articulate these actions, is to lead community garden groups (AND, 2013). In Brazil, the "Code of Ethics", which regulates the performance of nutritionists, states that this professional is committed to sustainable development and the preservation of biodiversity, which is one of the fundamental principles of the category (CFN, 2018).

However, the hegemonic approach of this science focuses on the nutrient, with little emphasis on food and the questions that relate to its origin, food biodiversity, and the impact of diets on the environment (Lang \& Barling, 2013). Therefore, there is a formative gap that makes it impossible for this professional to promote more sustainable food systems, where food biodiversity plays a central role (Jacob \& Araújo, 2020). This fragility is the cause and consequence of the lack of studies on the subject, precisely the lack of nutritional composition data and food consumption studies on these plants (FAO, 2017). Thus, we ask the following question: what can we do about professional training?

Michelle Jacob \& Fábio Araújo (2020) suggest that the Garden-Based Learning (GBL) method can be strategic for the development of competencies for nutrition in the context of food systems, among them, the knowledge of biodiversity. Maggie Gartman et al. (2016) state from their experience with undergraduate students in nutrition and dietetics that GBL increases literacy in Food Systems by preparing professionals for the challenges of their future careers.

GBL uses gardens for educational purposes (FAO, 2004). In this approach, students experiment and collaborate to act on problems of a transdisciplinary nature, stimulating new ways of communication, learning, and reflection in action, based on the issues brought by the garden. Scientific evidence relates this method to the recognition of biodiversity, awareness of the environmental problems and 
sustainability, promotion of community and social participation, increased consumption of fruits and vegetables, higher rate of learning compared to conventional methods of education and behavioral improvement (Gaylie, 2009; Aftandilian \& Dart, 2011; Ramos et al. 2013; Davis et al., 2015).

Based on this evidence, in 2017 was born the "Nutrir Community Garden", a project that integrates teaching, research, and extension activities at the Federal University of Rio Grande do Norte. Initially, as a teaching strategy, the garden was born as a practical result of discussions between professors from the departments of Nutrition, Botany, Ecology, and Agronomy. These professors, who teach classes to students of the Nutrition course, were actively involved with the idea of building and using a garden for educational purposes in this course. In 2019, the project received laboratory status, becoming the Nutrir Community Garden Laboratory, the LabNutrir.

Our goal in this paper is to argue that the GBL method can play a strategic role in biodiversity education in nutrition training. We do this by reporting the LabNutrir experience. We seek to answer the following questions: What are the main challenges for addressing biodiversity in nutrition? How are these limits discussed in LabNutrir with support from GBL? Besides, we present some examples of the practical use of the method.

After discussing the relevant literature in more detail in the next section, we describe our methods, based on a qualitative approach, and present the results, examining them. In conclusion, we highlight how the learning and barriers experienced in this experience contribute to a new way of thinking about nutrition training to guide it to promote food biodiversity.

\section{Nutrition, biodiversity and garden-based learning}

\subsection{Challenges to address biodiversity in nutrition}

We present two challenges that restrict the science of nutrition to the promotion of food biodiversity: one of a formative order and the other, consequently, of a technical nature.

Several governmental and non-governmental organizations highlight the need for training human resources in nutrition with the knowledge and the skills necessary to promote sustainable diets (FAO, 2014; UN, 2015; 2016). Sustainable diets are recognized for their potential to collaborate simultaneously with environmental and human health as they stimulate conscious consumption of food biodiversity and improve diet quality (Burlingame, 2012; Mason \& Lang, 2017; Lachat et al., 2018).

Tim Lang \& David Barling (2013) argue that this formative gap in nutrition is built due to the fragmentation of knowledge in the area. According to the authors, scientists divided into thinking traditions that challenge the approach to sustainable diets. First, there is nutrition that thinks of its problems as part of the life sciences, where there is a search for the explanation of phenomena by an increasingly refined biochemical and genetic perspective. A second, social, conceives of nutrition as a product of sociocultural determinants. The third, also called eco-Nutrition or environmental nutrition, with Malthusian heritage, comprises this science due to its dependence on biophysical factors such as soil, biodiversity, water, and climate. The three approaches offer fundamental contributions to 
the performance of nutrition professionals and the formulation and implementation of policies related to the promotion of sustainable diets. Among those three, there is a hegemony of the first tradition of thinking in the formation of the nutritionist. A result is a reductionist approach in professional practice, which prioritizes the look on the nutrient, disregarding food, and its relationships with humans (Scrinis, 2008).

We can perceive this weakness in the technical skills of the area. The perceptions that come from training schools build blind spots that limit access to certain concepts, techniques, and products that seem evident in other areas. This narrow understanding limits the ability of our tools to dialogue with the biological and cultural diversity in cross-cultural contexts (Hassel, 2014). Thus, nutrition science protocols express an explicit limitation. In addition to being a young science (less than a hundred years), nutrition has its roots in Europe. Therefore, its practice and instruments continue to have a broad Eurocentric cultural expression (Hassel, 2014; Mozaffarian et al., 2018). In this sense, we point out two main bottlenecks: insufficient food composition data of local biodiversity foods, especially UFP, and the inability of dietary survey tools to capture the consumption of regional plants with taxonomic accuracy (FAO, 2017; GFAR, 2017).

Insufficient nutritional composition data make it particularly challenging to assess the collaboration of a diversity of foods in diet composition (Burlingame et al., 2009; Gibson et al., 2017). For example, none of the 12 native species consumed in a Caatinga community studied by Paloma Cruz $\&$ her collaborators (2014) has composition data in the "Brazilian Food Composition Table", Taco in Portuguese, the primary tool for food composition consultation within national. Furthermore, the lack of data in Taco turns difficult for us to consider the relevant nutritional contribution of polyunsaturated fatty acids from purslane (Portulaca Oleracea L.), recognized as an essential source of omega-3 among leafy vegetables (Uddin et al., 2014). Besides, several factors are responsible for affecting the nutrient content of food, such as climate, agricultural practices such as fertilizer use, species maturity stage, species varieties, differences in nutritional composition, and cultivation (Mercadante \& Rodriguez-Amaya, 1991; Rodrigues-Amaya, 2008). All these factors highlight the relevance of composition analysis at the regional level.

In turn, the fragility of food consumption instruments can lead to a misinterpretation of the nutritional contribution of the food consumed. We can highlight the difference of more than $30 \%$ in the potassium content of banana-figo and banana-maçã available from Taco (NEPA, 2011). Regarding the number of carotenoids, some bananas may have up to 8,500 times more beta carotene when compared to other varieties (Burlingame et al., 2009). Among some sweet potato cultivars, the difference can reach 176 times the amount of provitamin-A (Jesus et al., 2017). Some researchers found a variation of 5.6 to $14.6 \%$ in protein content in rice cultures (Burlingame et al., 2009)

The nutrition tool's limits create a recursive problem. It is unproductive to collect consumption data that will not be analyzed adequately due to the lack of indicators of the nutritional composition. On the other hand, it does not make sense to produce plant composition studies on plants that, theoretically, are not consumed. 


\subsection{Opportunities generated by the garden- based learning method}

The GBL method is a pedagogical strategy that uses gardens as teaching and learning spaces. Its primary theoretical basis comes from experiential education, a current of thought that argues that the involvement of educators and learners in direct experience and focused reflection contributes to the construction of meaningful knowledge and the development of skills and attitudes that help to community life (AEE, 2002). Children and young people have less contact with nature, which has generated physical problems, such as obesity, and mental issues, such as depression, hyperactivity, and attention deficit (Louv, 2008). Living with the garden ecosystem - which involves, besides the flora, a macro and microscopic fauna and the collective of people who interact with each other - facilitates the generation of learning situations focused on the experience. The GBL, moreover, stands out for fostering the active participation of students, hosting complex problems involving different systems and actors, and being guided by the local reality (FAO, 2004).

In a literature review study on the impact of GBL on schools, Dilafruz Williams \& Scott Dixon (2013) state that the main strategies used in the context of the programs analyzed were: practice-based curriculum, culinary education, and use of the garden as the central point of the training. Among the 48 studies reviewed by the authors, published between 1990 and 2010, the academic results related to the method pointed to a positive impact on the acquisition of science-related knowledge, followed by Mathematics and Language. According to the authors, the results were consistent between programs, student samples, types of schools, and among the different research methodologies used. Joanne Pascoe \& Claire Wyatt-Smith (2013), in an intervention study at elementary schools in Queensland, Australia, found similar results, highlighting environmental literacy, including the topic of biodiversity. Also, in northeastern Brazil, in a primary education school in Paraíba, Santos et al. (2014) found that the garden contributed to the improvement of the teaching-learning process. In this case, there was greater interdisciplinarity, cooperation, awareness of students about environmental problems and sustainability, and promoting changes in the eating habits of students via school feeding.

GBL's positive correlation with environmental science and education explains its recurrent use as a biodiversity education strategy (Yli-Panula et al., 2018). Biodiversity education includes three key aspects: species identification, a more microscopic understanding of phylogeny, and the relationship of these individuals to ecosystems. Recent studies highlight a fourth aspect: the indivisibility of the cultural component in biodiversity analysis (Yli-Panula et al., 2018). GBL offers a scenario that reconnects these different aspects of biodiversity education because it stimulates systemic thinking, holistic view, cultural literacy, and sustainable development (Ehrlich \& Pringle, 2008; Pascoe \& Wyatt-Smith, 2013).

Skills development and human resource training is a crucial strategy for guiding efforts around biodiversity conservation, especially in developing countries (UN, 2011). The Rio +20 conference, for example, highlighted the need for universities, especially those in developing countries, to put together educational projects that can fill professional gaps 
for the pursuit of sustainable development goals at the national and local levels (UN, 2012). This call is undoubtedly a challenge for nutrition professionals, as food and diets are among the leading social determinants of human and environmental health (FAO, 2014). The injustices produced by the current food system make it urgent to transform our strategies to promote sustainable diets based on fair food, with cultural representation, and based on local biodiversity (Burlingame, 2012).

In the previous section, we discussed how fragmentation in nutrition education constitutes a limit to addressing biodiversity. Tim Lang \& David Barling (2013) point out three traditions of thinking: social, biological, and environmental. We argue that the teaching of biodiversity with the support of the GBL method can help in approaching this limit, operating the reconnection of knowledge. We affirm based on two main reasons. First, biodiversity education is grounded in aspects that reflect these traditions of thinking. Second, GBL encourages learning situations where the social, biological, and environmental are reconnected.

Some evidence demonstrates the potential of GBL in nutrition training. Michelle Jacob et al. (2018), in a study that evaluated the educational potential of a university garden project in the Rio Grande do Norte, Brazil, with practices integrated into the nutrition curriculum, point out three main results: the acquisition of technical knowledge related to agroecology, food systems, biodiversity, and sustainability; acquisition of research skills, community project management, and teamwork; acquisition of attitudes about community belonging, citizenship, and social responsibility.

In a study that looked at the benefits, barriers, and facilitators of student engagement in a university garden project in Queensland, Australia, Courtney Anderson et al. (2018) highlighted the participation of nutrition students in the program. These students, among the representatives of various courses, demonstrated high engagement, participating in the project from the initial design phase, staying in it during implementation and management. Students listed the lessons learned from the development of sustainable food systems and diets among the educational benefits reaped from the program. Added to the positive academic results are the opportunity for applied education and research, learning useful services for the community, experience in project management, integration of different disciplines. The incorporation of the garden into the curriculum was crucial to foster students' participation.

Dave Aftandilian \& Lyn Dart (2011) in Texas, USA, used GBL undergraduate to improve teaching practices, particularly by strengthening campus-community ties. Developing communication skills among actors, cooperation, and a sense of social justice are among the main strengths reported by the authors.

The evidence listed above shows that the GBL method has the potential to collaborate in training professionals to work with biodiversity because it articulates different approaches to nutrition (social, environmental, and biological), linking different areas involved in promoting sustainable food systems. (such as agronomy, ecology, botany, anthropology) integrates participants with local flora and ultimately creates opportunities for sharing knowledge associated with plants.

Among the significant challenges for implementing the method are competing priorities in training, especially as garden projects do not yet have institutional pedagogical status, frequently 
being considered by scholars as optional activities. Other challenges involve a lack of communication between project members and a lack of information (FAO, 2004; Anderson et al., 2018). Studies that directly assess the impact on the university environment with nutrition students may further qualify this debate.

\section{Method}

\subsection{Study type}

The study has a qualitative and exploratory approach, experience report type. As far as we know, the proposal for reflection on biodiversity education using the GBL method in the university environment in a Nutrition course is unprecedented. Exploratory research, in this case, can help us in defining the research object and defining analytical categories for future research focused on training. We justify the choice of the experience report format to operate a reflexive exercise on our experiences as students and teachers involved in LabNutrir. The formative experiences are born from this reflective process about the experiences, also called pre-reflexive experiences (Passeggi, 2011).

\subsection{Study scenario}

LabNutrir, Laboratory Community Garden Nutrir, is in the Department of Nutrition of the Federal University of Rio Grande do Norte (UFRN, in Portuguese), in Natal, Northeast Brazil. Natal (Latitude: $5^{\circ} 47$ ' $40^{\prime}$ 'S, Longitude: $35^{\circ} 12^{\prime} 40$ ' W), capital of Rio Grande do Norte, has the largest population in the state, estimated at 884,122 (IBGE, 2019).

UFRN, which celebrated its $60^{\text {th }}$ anniversary in 2018, offers 113 undergraduate courses, 86 master's degrees, 41 doctorates, serving a student community of over 43,000 students. The Nutrition course, where LabNutrir is located, has 42 years.

\section{Results and discussion}

\subsection{LabNutrir history and functioning}

The idea of using the GBL method at UFRN emerged in 2017 as a formative proposal in the nutrition program, built with the support of various knowledge areas and in dialogue with the community. The method that has guided project activities since its inception is GBL. The institutionalization of the vegetable garden in the laboratory in 2019 enables better infrastructure, human resources support, and longevity of the practice.

LabNutrir has the direct performance of five professors from the areas of nutrition, ecology, and agrarian sciences. Three technical servers collaborate directly with the demands generated by the laboratory. On average, 15 nutrition students work with space management. The number of permanent project volunteers ranges from 20 to 30 people. Since August 2019, we add the adopter category to the list of volunteers. Adopters are volunteers who are responsible for one of the flowerbeds of space and can arbitrate their production. In addition to these actors, during joint efforts sessions - that take place on the first Saturday of each month - about 30 people collaborate on time. 

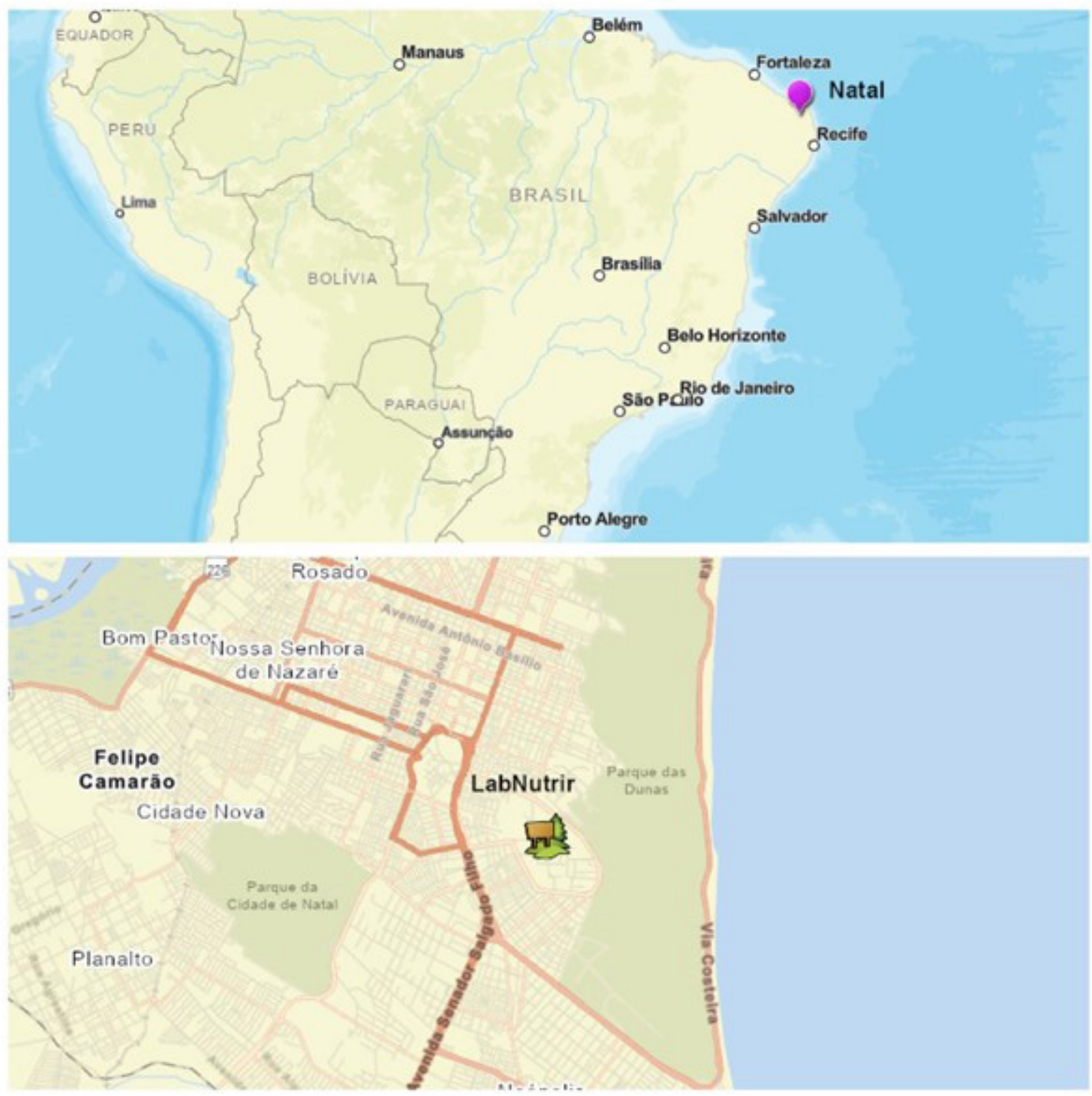

FIGURE 1 - Study scenario with highlights in Natal and LabNutrir.

SOURCE: Own elaboration with ArcGis. 
In teaching, LabNutrir works in dialogue with the following curriculum components of the Nutrition course: Sustainable food systems, Socioanthropological aspects of food; Food and nutrition education, and Elements of agroecology. The classes take place from the interaction with the garden and involve culinary workshops. In extension, LabNutrir welcomes the external community in their monthly collaborations and has an action in the metropolitan region of Natal that consists of the implementation of school gardens. To date, we implemented seven school gardens in Natal and its metropolitan area with support from LabNutrir, reaching almost 3,000 students from public schools. In research, the focus is on mapping the food plants of local biodiversity.

LabNutrir is structured in a $1,200 \mathrm{~m}^{2}$ physical space, divided into various beds, scattered plantings, an orchard, a pollinator garden, composting space, nursery seedlings, bee houses, two circular wheels for group conversations, and an area for tool storage. We do not use chemical or pesticide-based fertilizer in the garden - our cultivation plan relies on agroecological bases. The laboratory also has the support of a test kitchen, part of the structure of the Department of Nutrition. We present some visual details in Figure 2.

At LabNutrir, we classify plants according to their botanical families, origin, conventionality criteria, and food group. The laboratory plant population consists of 131 edible species distributed in 55 different botanical families, $27 \%$ native, and
$49 \%$ UFP or Medicinal. Considering the part of the plant with the highest edibility potential in the region, $70 \%$ of the individuals are representatives of the food group "vegetables" according to the classification of the "Food Guide for the Brazilian Population" (Brazil, 2014) ${ }^{1}$.

The United Nations have recognized this practice as an initiative that collaborates to promote food as a human right. The publication of the experiment was entitled: "Community gardens to food democracy: Right to Adequate Food, higher education, and awareness-raising through the approach of sustainable food systems in the Brazilian northeast"2. Besides, LabNutrir was prized by the "ODS-Brazil Award" which aims to encourage, value and give visibility to practices that contribute to achieving the objectives and goals of the 2030 Agenda for Sustainable Development in the Brazilian territory ${ }^{3}$. LabNutrir aligns with the following Agenda 2030 objectives: $2,3,4,11,12,13$, and 15 .

\subsection{Biodiversity and its approach in nutrition: the GBL method in practice}

Each academic semester, we select four UFP that guide our work in the areas of teaching, research, and extension. Biodiversity is directly present in four curriculum components (see Table 1). In all of them, we study the same plants, focusing on an aspect, which dialogues with contents in each program.

\footnotetext{
${ }^{1}$ LabNutrir's plant inventory is available on its website: http://www.nutrir.com.vc

${ }^{2}$ The experience report is available at https://bit.ly/2pjcKYX

${ }^{3}$ The project report entitled Community Garden Nutrition: Nutrition for Sustainable Development in Food and Nutrition Training is available at https://bit.ly/2mV7ji7
} 

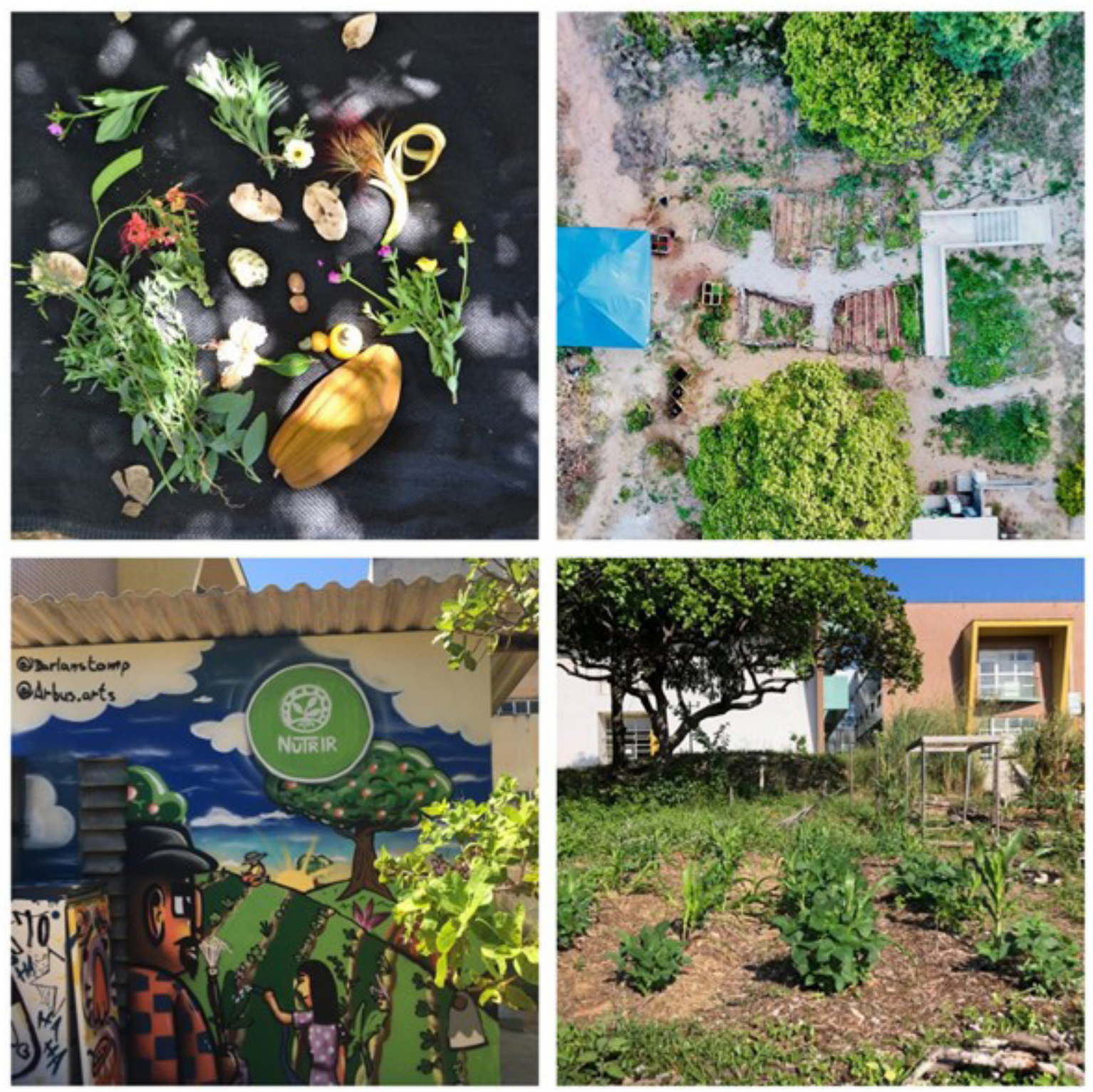

FIGURE 2 - LabNutrir details and plants. Left to right, clockwise: UFP collected in LabNutrir area, aerial and front view in 2019, art on the side of the tool keeper's house.

SOURCE: LabNutrir archive. 
TABLE 1 - Curriculum articulation with biodiversity.

\begin{tabular}{ll}
\hline \multicolumn{1}{c}{ Courses } & Contento on Biodiversity \\
\hline Socioanthropological aspects of food & Plant Identification. Ethnobotanical survey. \\
Agroecology elements & Ecology of the species. Agroecological management. \\
Sustainable food systems & Systems theory. Collection of nutritional indicators. Sustainability. Ethnoculinary. \\
Food and nutrition education & Health promotion. Community-based projects. \\
\hline
\end{tabular}

SOURCE: Research data.

Suppose we are studying Pachira aquatica Aubl. (monguba). In the discipline of Socioanthropological aspects of food, priority is given to contents and situations related to food culture, local names, and uses related to monguba. In Agroecology elements, the agroecological management of this plant and data related to the ecology of the species is the keynote. In Sustainable food systems, the plant is analyzed from a holistic perspective, from its production to its consumption, favoring the approach on local preparation techniques and collection of nutritional indicators. Finally, in Food and nutrition education, we develop practical strategies to stimulate the consumption of these plants, focusing on the community and the food environment. In this process, students develop the field and bibliographic research focusing on these plants. At the end of each semester, we compile the data in synthesis sheets. They serve as the basis for the development of various academic and community actions.

For example, the plants studied in the first semester of 2019, the focus of this experience report, were: Moringa oleifera L. (moringa), Eugenia pyriformis Cambess (ubaia), Cyperus esculentus L. (tiririca), and Momordica charantia L. (melão-de-são-caetano). We present these plants in Figure 3. to discuss the following questions:

- How to identify these plants?

- How do local people recognize and interact with these vegetables?

- Where are these vegetables from?

- What are your botanical families?

- What are the best practices of agroecological management?

- What are your nutritional indicators?

- What other sustainability indicators justify promoting the use of these plants?

- How to process these foods to be fit (anti-nutritional factors) and attractive (taste and presentation) for human consumption?

- What is the best way to promote your consumption, either with individuals or groups?

We try to find the answers to these questions in our practices in the different curriculum courses in the nutrition program. The challenges we face in this process converge with those presented in this article when we discuss the limits to address biodiversity in nutrition. In Table 2 , we offer a summary of these difficulties and some strategies outlined by us to address them in LabNutrir with the UFP theme. 

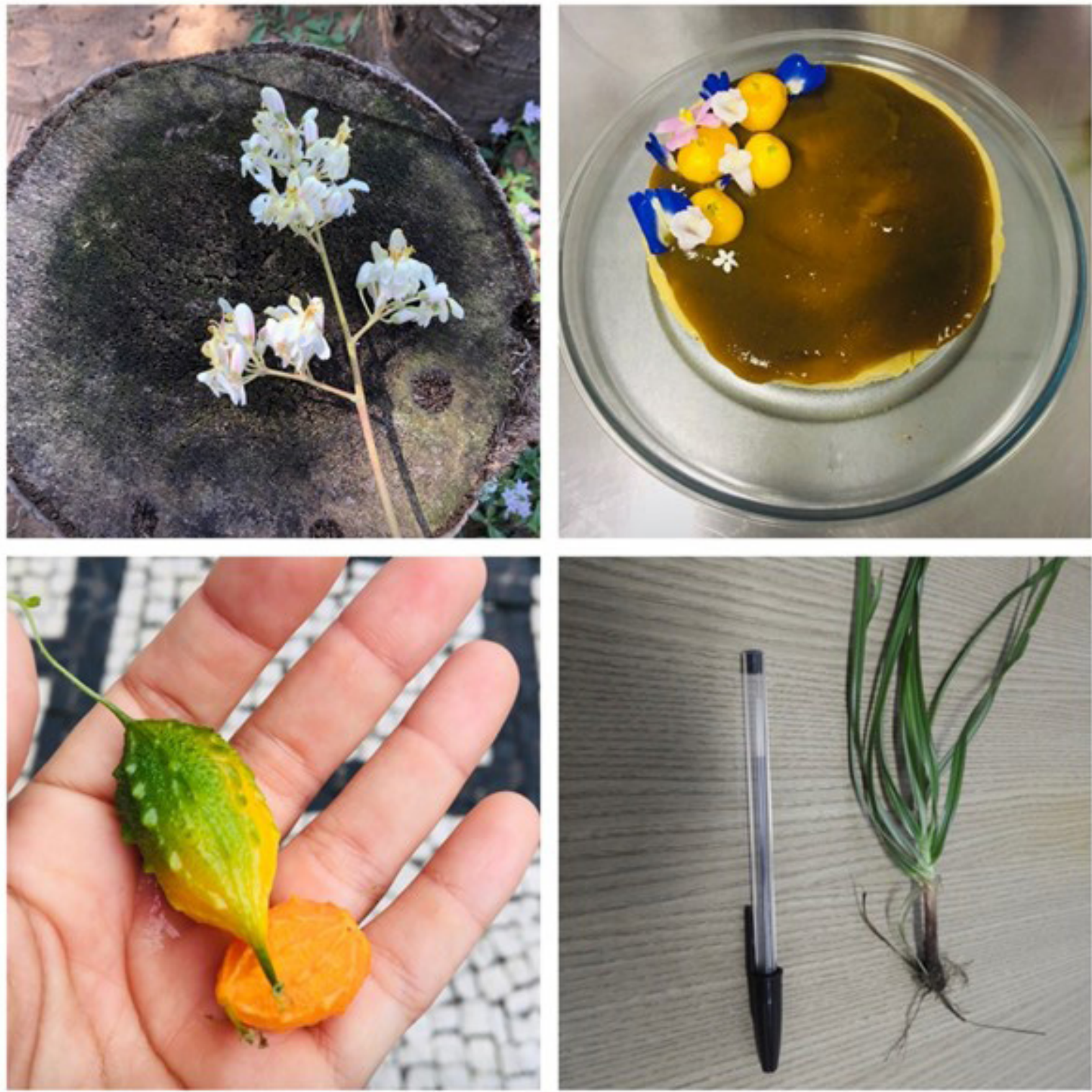

FIGURE 3 - UFP studied in 2019 first semester, LabNutrir, Natal, Brazil. From left to right, clockwise. Flowers of Moringa oleifera L. (moringa); vegan cheesecake of Eugenia pyriformis Cambess (ubaia); rhizome and leaves of Cyperus esculentus L. (tiririca); fruits of Momordica charantia L. (melão-de-são-caetano).

SOURCE: LabNutrir archive. 
TABLE 2 - Challenges for promoting biodiversity and our strategies in LabNutrir.

\begin{tabular}{|c|c|c|}
\hline \multirow{4}{*}{ Educational } & & Nutrition professors with interdisciplinary training \\
\hline & & Curriculum approach \\
\hline & $\begin{array}{l}\text { Insufficient dialogue with other } \\
\text { areas of knowledge }\end{array}$ & Multiprofessional projects \\
\hline & & Access to databases from other areas \\
\hline \multirow{4}{*}{ Technical } & & Use of ethnobotany and anthropology techniques \\
\hline & & Food matching \\
\hline & Lack of data & Data collection \\
\hline & & Data production \\
\hline
\end{tabular}

SOURCE: Research data.

We address educational challenges using the strategies of professor's training, LabNutrir institutionalization, and curriculum approach. On the first point, we affirm that the formation of coordinating professors is one of the elements that enable the reconnection of social, environmental, and biological aspects of the diet. The professors are nutritionists with complementary training in areas such as ethnobiology, social sciences, and education. Due to the diversity of knowledge that working with active methodologies requires, the reflection on the formation of professors that mediate such processes is essential to the excellent coordination of the project (Diesel et al., 2017).

Regarding the second, the lack of management infrastructure and physical space to install the gar- den are among the main challenges for the implementation of the GBL method. These facts justify the decision of the nutrition's professors at UFRN to insert LabNutrir into the course's lab portfolio, institutionalizing it. It will provide the material structure that the lab needs to maintain its activities.

The third and last point emphasizes the insertion of biodiversity practices in the curriculum of the nutrition program. It fosters a content approach in the whole nutrition program and does not link discussions to the voluntarism of individual professors. Moreover, the prediction of a transdisciplinary component entitled Sustainable food systems is strategic especially in a scenario where curriculum structure is limited by fragmented models of disciplines, content, and specialized activities (Jacob 
\& Araújo, 2020). Sustainable food systems course thus consolidates the discussion going to the parts until the whole and vice-versa.

Other garden projects with university students present similar evidence. Maggie Gartman et al. (2016) point to the following results, in an investigation that examined the development of competencies with nutrition students in a garden program in North Carolina, USA: increased connection with community organizations, improved recognition and consumption of local plants, and strengthening of skills in horticulture and food and nutrition education. In the students' opinion, the garden program prepares them for their future careers, starting from the work of nutritional counseling to public policy actions focused on sustainable development.

For Cheang et al. (2017), GBL supports education for sustainability by strengthening powerful learning environments for college students. In their study, which analyzed the perspectives of actors involved in the implementation of a vegetable garden on a university campus in Hong Kong, the authors highlight the results related to communication, especially between local community members and students, as well as the integration of educational activities. Veronika Gaylie (2009) - one of the pioneers of the method with higher education students in Vancouver, Canada - states that the GBL in a higher education environment alters students' attitudes towards the environment, displacing them from an anthropocentric perspective, fostering critical thinking and environmental and social justice.

Biodiversity issues, however, are not limited to nutrition. Beyond the disciplinary level, we address the problem of insufficient dialogue with other areas of knowledge at LabNutrir with partnerships with people from different fields of expertise. Our partners are students and professors from other departments, including ecology and agronomy and, more recently, postgraduate social sciences and ethnobiology programs. The design of research projects with multidisciplinary teams, with nutrition students participating in its development and discussions, broadens the understanding of the food problem and the theoretical and methodological horizons for its approach.

Dialogue with other knowledge circles exposes blind spots in our area (Morin, 2015). Therefore, in the learning process about these plants, nutrition students are presented with research tools, many of them unknown to health sciences students, such as the "Flora do Brasil 2020" database (Rio de Janeiro Botanical Garden), “The Plant List" (Royal Botanic Gardens, Kew and the Missouri Botanical Garden), the "Brazilian Biodiversity Information System" ( $\mathrm{SiBBr}$, abbreviated form in Portuguese) and the "EMBRAPA Agricultural Research" database.

We perceive the technical challenges concerning the lack of available tools and data. Regarding the tools, there is a consensus that in nutrition, they are often devoid of the local context, which limits the approach and promotion of consumption of local plants (Hassel, 2014; FAO, 2017). To bridge this gap, LabNutrir students are encouraged to interact with regional biological and cultural diversity using research techniques in ethnobiology and anthropology. By studying the plants selected each semester, students survey the different applications and meanings attributed to local biodiversity. Besides, they are encouraged to evaluate dietary survey tools, such as the $24 \mathrm{~h}$ Recall, to engage in dialogue with cross-cultural contexts. Interaction with fixed community volunteers is another source of learning. These volunteers are people with a 
distinct background, age, and education, many of them with extensive plant knowledge. The focus on cultural diversity represented by laboratory members and their different backgrounds is a focus on broadening the look at biological diversity (Lévi-Strauss, 2011). The exchange of knowledge with these groups enables the construction of multiple sources of evidence on biodiversity, favoring cultural data, especially knowledge associated with plants (Albuquerque et al., 2019).

Analyzing the educational and technical challenges, we infer that progress towards the promotion of food biodiversity depends, in addition to disciplinary growth, on the collaboration between different fields of knowledge in the task of adapting tools so that they dialogue with varying contexts. One way to build articulation between various fields of expertise in the health area is through teaching projects based on active methods (Araújo et al., 2016)

The barriers raised are also instrumental in that they are unable to capture food composition data from local biodiversity, making an efficient assessment of food diversity in diet composition impossible. It is commonplace in Nutrition that one of the significant gaps in addressing biodiversity is the lack of food composition indicators. The dietary composition indicator, in each system, refers to at least one value for calories, macronutrients, micronutrients, bioactive compounds, for each species presented (FAO, 2017). In the impossibility of directly analyzing food, which is not always possible given the cost of research, the recommendation is the application of Food Matching (Stadlmayr et al., 2012), a concept introduced to students. Food matching (FM) is an analysis strategy that links consumption and supply data with food composition data available in tables and databases. The goal of FM is to perform the highest quality match by identifying the most appropriate matching food in the most relevant composition table. How does FM work? First, the researcher should define the set of research reference tables. Second, in the absence of food information on these reference tables, FAO recommended searching for correspondence with scenarios, countries, or approximate foods. The proposed order of correspondence according to the guidelines is as follows: scientific articles; theses; international food composition tables; reports; and finally, labels. Finally, if there is no information in any of the sources, the suggestion is to average three approximate items in the reference table.

The primary sources of biodiversity data presented to students at LabNutrir are the "Brazilian Biodiversity Information System” (SiBBr), the "Brazilian Food Composition Table" (Taco, Unicamp), and the biodiversity and regional foods module of the "Brazilian Food Composition Table" (Tbca, USP). In the absence of plant composition data understudy from these sources, we should apply FM guidelines. To exemplify, Table 3 summarizes the macronutrient data gathered by the students in 2019. We show values for specific plant parts (fruit, leaves, seed) separately when available. Whitespace refers to data not available or not found.

According to FAO (2015), indicators to monitor the progress of an environmentally sustainable diet should integrate its quality associated with local biodiversity. For Carl Lachat et al. (2017), identifying species diversity is a useful first step in assessing the sustainability of diets. Conservation interventions and nutrition-sensitive ecosystems, especially those related to diversification, clearly have untapped potential to minimize world hunger and micronutrient deficiency. 
TABLE 3 - Nutrition composition data from UFP studied in LabNutrir, Natal, Brazil, 2019.

\begin{tabular}{|c|c|c|c|c|c|c|}
\hline Scientific Name & Analyzed Part & Energy (Kcal) & Carbohydrate (g) & Protein (g) & Fat (g) & Total Fiber (g) \\
\hline Moringa oleifera $\mathrm{L}$. & Fresh leaf $^{1}$ & 84 & 8.28 & 9.40 & 1.40 & 2.00 \\
\hline Eugenia pyriformis Cambess & $\begin{array}{l}\text { Fresh pulp with } \\
\text { peel }^{3}\end{array}$ & 21 & 4.87 & 0.55 & 0.12 & 1.00 \\
\hline Momordica charantia L. & Fresh fruit $^{5}$ & 242 & 34.31 & 1.00 & 0.17 & 2.80 \\
\hline Momordica charantia $\mathrm{L}$ & $\begin{array}{l}\text { Seeds and peri- } \\
\text { carp }^{6}\end{array}$ & 218 & 9.18 & 19.50 & 11.50 & - \\
\hline
\end{tabular}

SOURCES: ${ }^{1}$ Teixeira (2012); ${ }^{2}$ Leone, et al. (2016); ${ }^{3} \mathrm{SiBBr}(2019) ;{ }^{4}$ El-Shebini et al. $(2010) ;{ }^{5}$ USDA (2018); ${ }^{6}$ Bakare et al. $(2010)$.

We summarize some additional information collected and edited by students who participated in various curriculum components linked to LabNutrir, as an example in Figure 4.

The exercise of constructing this framework and gathering information on UFP directly or indirectly addresses all the key challenges listed in Table 2. Also, the consolidation of this information into descriptive sheets serves as a culminating pedagogical strategy for the collective work developed each semester (Hernández \& Ventura, 2016). We compile all information collected or produced about plants in these sheets, such as scientific and vernacular names, origin, the biome of occurrence, culinary uses, nutritional indicators, and others. These cards embody LabNutrir's transdisciplinary experience in a tangible product. Besides, this material serves as a basis for the development of scientific communication and food and nutrition education actions in the community. We hope to be empowering students in this way to provide a relevant service to the population with locally available and accessible plant databases.

\section{Final considerations}

The correlation between human and environmental health is increasingly evident. Recent debates on the global Syndemic, characterized by the integrated advance of the obesity, malnutrition, and climate change pandemics, testify to this statement. In this context, scientist argues the recognition and conservation of food biodiversity as the most effective way to sustainability. In nutrition science, this agenda is formed - as a field of research, action, and training - by the concept of sustainable diets. Despite widespread dissemination of sustainable diets, understanding how to set goals, evaluate processes, and choose indicators is insufficient. We link the challenges of promoting sustainable diets with professional competence and a consequent technical issue related to available tools and data for the promotion of local plants. 
Moringa oleifera L. is a tree in the Moringaceae family, native to northeastern India. Composition studies show that leaves, flowers, and seeds have excellent nutritional as well as medicinal properties. Eugenia pyriformis Cambess, better known popularly as ubaia, is a species of fruiting plant that has medicinal, industrial, and gastronomic properties. Belongs to the Myrtaceae family, is commonly found in regions of Argentina, Paraguay, and Brazil, and is native to the Atlantic Forest. Its fruits have a pleasant taste. Cyperus esculentus L., popularly identified as tiririca or tiger nut, is a perennial plant with rhizomes and leafy tubers of yellow to green color. In several regions, Cyperus esculentus $L$. is considered a weed. However, many are unaware of their food potential and medicinal importance. Cyperus esculentus L. contains in its composition fatty acids, vitamins, and phenolic compounds that are beneficial to health. Momordica charantia L., known as melãode-são-caetano, belongs to the Cucurbitaceae family and is mostly found in tropical regions. Despite being exotic, it is born spontaneously in several Brazilian locations. It is well known and used for its medicinal and dietary qualities.

FIGURE 4 - Information gathered by students on some unconventional food plants studied in LabNutrir.

SOURCE: Prepared by students based on data from Ramachandran et al., (1980), Foidl et al. (2001), Myojin et al. (2008), Sartori et al. (2010), Manek et al. (2012), Lamarca et al. (2013), Shakerin et al. (2019), Jia et al. (2017), Vega-Morales et al. (2019).

We use the case of the UFP because they are emblematic concerning these aspects. In our experience, the use of the GBL method has provided several opportunities to address each of these limits: from reflection on teacher education and curriculum, creation of thematic projects with multi-professional staff, development of research skills on topics located at the frontiers of knowledge. We are strengthening ties with the community. In these actions, we systematically approach knowledge about taxonomy, phylogeny, ecosystems, and cultural diversity. We believe, therefore, that the GBL method plays a strategic role in the development of competencies and skills in nutrition training to promote sustainable diets. Besides, students report that LabNutrir experience contributes significantly to their awareness of biodiversity and the relevance of environmental issues.

Maintaining a garden in an institutional space requires time, human and material resources. However, given the innovation of the proposal, we realize today that the main barrier found in its consolidation was the natural resistance to all processes of disruption in the field of ideas. Two initial strangenesses stand out: the sense of a laboratory without walls and garden space in the nutrition course. These conceptions eventually demanded an extra effort of peer convincing and vigilance through the institutional and extra-institutional windows of opportunity that could act to strengthen this practice validation process. The idea of drawing up this experience report, therefore, serves as a way of encouraging similar initiatives.

The scarcity of available literature on the subject has limited our ability to analyze this work within a previous frame of reference. We hope to develop research in the future to measure the impact of these GBL strategies on capacity building for biodiversity work. The purpose is to produce specific data on the effects of GBL on education for biodiversity, based on education indicators, broadening the scope of available evidence and, consequently, the quality of the academic debate on the topic. 


\section{Acknowledgment}

Sincere gratitude to all members of LabNutrir, including students, professors, staff, and external community members. Many thanks to those members that provided beautiful images to our archive. Some of these pictures can be seen in this paper. We are also grateful for the additional comments provided by the anonymous reviewers.

\section{References}

AEE - Association For Experiential Education. What is Experiential Education?, 2002. Available at: <www.aee. org>. Access on: apr. 2019.

Aftandilian, D.; Dart, L. Using Garden-Based Service-Learning to Work Toward Food Justice, Better Educate Students, and Strengthen Campus- Community Ties. Journal of Community Engagement and Scholarship, 6(1), 55-70, 2011. Available at: http://jces.ua.edu/using-gardenbased-service-learning-to-work-toward-food-justice-bettereducate-students-and-strengthen-campus-community-ties/

Albuquerque, U. P.; Nascimento, A. L. B.; Soldati, G. T.; Feitosa, I. S.; Campos, J. L. A.; Hurrel, J. A; Hanazaki, N.; Medeiros, P. M.; Silva, P. R. V.; Ludwinsky, R. H.; Júnior, W. S. F.; Reyes-García, V. Ten important questions/issues for ethnobotanical research. Acta Botanica Brasilica, 33(2), 376-385, 2019. doi: 10.1590/0102-33062018abb0331

AND - Academy of Nutrition and Dietitics. Sustainable, Resilient and Healthy Food \& Water Systems. AND, 2013. Availabe at: $<$ https://eatrightfoundation.org/why-it-matters/ public-education/future-of-food/sfs/>. Access on: dec. 2019.

Anderson, C.; Maher, J.; Wright, H. Building sustainable university-based community gardens: Volunteer perceptions of enablers and barriers to engagement and benefits received from volunteering in the moving feast. Cogent Social Sciences, 4(1), 1-19, 2018. doi: 10.1080/23311886.2018.1488211

Andrade-Cetto, A.; Heinrich, M. Mexican plants with hypoglycaemic effect used in the treatment of diabetes. Journal of Ethnopharmacology, 99(3), 325-348, 2005. Available at: https://www.ncbi.nlm.nih.gov/pubmed/15964161

Araújo, A. F.; Oliveira, M. A.; Abreu, J. V.; Souza, E. C., Pequeno, A. M. C.; Gomes, A. M. A.; Machado, M. F. A. S.; Rodrigues, D. C.; Rebouças, T. O; Napoleão, C. M.; Salomão, A. M. A.; Bruno, G.; Guimarães, J. M. X. Active Methods of Teaching-Learning in the Health Area: The Problems In Nursing Education. International Archives of Medicine, 9, 1-7, 2016. Available at: https://imed.pub/ojs/ index.php/iam/article/view/1450/1145

Bakare, R. I.; Magbagbeola, O. A.; Akinwande, A. I.; Okunowo, O. W. Nutritional and chemical evaluation of Momordica charantia. Journal of Medicinal Plants Research, 4(21), 2189-2193, 2010. Available at: http://mtu.edu. ng/mtu/oer/journals/135-article1380538976_Bakare\%20 et $\% 20$ al $\% 20$ Pdf.pdf

Brasil. Hortaliças não-convencionais. Brasília: Ministério da Agricultura, Pecuária e Abastecimento, 2010.

Brasil. Ministério da Saúde. Guia alimentar para a população brasileira. 2. ed. Brasília: Secretaria de Atenção à Saúde/Departamento de Atenção Básica, 2014.

Burlingame, B. Sustainable Diets and biodiversity. Rome: FAO, 2012.

Burlingame, B.; Charrondiere, R.; Mouille, B. Food composition is fundamental to the cross-cutting initiative on biodiversity for food and nutrition. Journal of Food Composition and Analysis, 22(5), 361-5, 2009. Available at: https://www.sciencedirect.com/science/article/abs/pii/ S0889157509001525

CFN - Conselho Federal De Nutricionistas. Resolução n.600/2018. Brasília: CFN, 2018.

Cheang, C. C.; Winnie, S.; Zhan, Y.; Tsoi, K. H. Education for sustainability using a campus eco-garden as a learning environment. International Journal of Sustainability in Higher Education, 18(2), 242-262, 2017. doi: 10.1108/ IJSHE-10-2015-0174

Cruz, M. P.; Medeiros, P. M.; Sarmiento-Combariza, I.; Peroni, N.; Albuquerque, P. U. "I eat the manofê so it is not forgotten": Local perceptions and consumption of native wild edible plants from seasonal dry forests in Brazil. 
Journal of Ethnobiology and Ethnomedicine, 10(1), 2014. Available at: https://www.ncbi.nlm.nih.gov/pmc/articles/ PMC4038053

Davis, J. N.; Spaniol, M. R.; Somerset, S. Sustenance and sustainability: Maximizing the impact of school gardens on health outcomes. Public Health Nutrition, 18(13), 2358-67, 2015.

Diesel, A.; Baldez, A. L. S.; Martins, S. N. Os princípios das metodologias ativas de ensino: uma abordagem teórica Active teaching methodologies principles: a theoretical approach. Revista Thema, 14(1), 268-88, 2017.

Ehrlich, P. R.; Pringle, R. M. Where does biodiversity go from here? A grim business-as-usual forecast and a hopeful portfolio of partial solutions. PNAS, 105(1), 11579-11586, 2008. Available at: https://www.pnas.org/content/pnas/105/ Supplement_1/11579.full.pdf

El-Shebini, S. M.; Moaty, M. I. A.; Tapozada, S. T.; Hanna, L. M.; Mohamed, H. I.; Raslan, H. M. Effect of Regular Consumption of Tiger Nut (Cyperus Esculentus) on Insulin Resistance and Tumor Necrosis Factor-Alpha in Obese Type 2 Diabetic Egyptian Women, Medical Journal of Cairo University, 78(2), 607-614, 2010. Available at: http://medicaljournalofcairouniversity.net/home2/images/ pdf/2010/December/30.pdf

FAO - Food And Agriculture Organization of the United Nations. Revisiting garden-based learning in basic education. Rome: FAO, 2004.

FAO - Food And Agriculture Organization of the United Nations. Second Report on the State of the World's Plant Genetic Resources for Food and Agriculture. Rome: FAO, 2010.

FAO - Food And Agriculture Organization of the United Nations. Second International Conference on Nutrition. Rome: FAO, 2014.

FAO - Food And Agriculture Organization of the United Nations. Guildelines on assessing biodiverse foods in dietary intake surveys. Rome: FAO, 2017.

Foidl, N.; Makkar, H.; Becker, K. The potential of Moringa oleifera for agricultural and industrial uses. In: Lowell, J. The miracle tree: The multiple attributes of Moringa. Dakar,
Senegal: Church World Service, 2001. p. 45-76.

Gartman, M. et al. Design and Implementation of a Garden-Based Service Learning Program for Nutrition and Dietetic Students: A CBPR Approach. Journal of Nutrition Education and Behavior, 48(7), S60, 2016.

Gaylie, V. The Learning Garden: Ecology, Teaching, and Transformation. New York: Peter Lang, 2009.

GFAR - Global Facilitation Unit for Underutilized Species. Progress Report. University of Edinbrugh, 2017. Available at: < http://www.fao.org/docs/eims/upload/237670/PC_11_ GFUUS_Nov07.pdf >. Access on: dec. 2019.

Gibson, R. S.; Charrondiere, U. R.; Bell, W. Measurement Errors in Dietary Assessment Using Self-Reported 24-Hour Recalls in Low-Income Countries and Strategies for Their Prevention. Advances in Nutrition, 8(6), 980-991, 2017.

Hassel, C. A. Reconsidering nutrition science: Critical reflection with a cultural lens. Nutrition Journal, 13(1), 1-11, 2014.

Hernández, F.; Ventura, M. A organização do curriculo por projetos de trabalho. São Paulo: Penso, 2016.

IBGE - Instituto Brasileiro de Geografia e Estatística. Natal. Available at: $<$ https://cidades.ibge.gov.br/brasil/rn/natal/ panorama $>$. Access on: dec. 2019.

Ipes-Food - International Panel of Experts on Sustainable Food Systems. From Uniformity to Diversity: A paradigm shift from industrial agriculture to diversified agroecological systems. Belgium: Ipes-Food, 2016.

Ipes-Food - International Panel of Experts on Sustainable Food Systems. Unravelling the Food-Health Nexus: Addressing practices, political economy, and power relations to build healthier food systems. Belgium: Ipes-Food, 2017.

Jacob, M.; Rodrigues, T.; Macedo, J.; Alves, M.; Guedes, R.; Cunha, T. Garden-based learning no ensino superior: reflexões sobre o método a partir da monitoria da Horta Comunitária Nutrir. In: Anais do Encontro Integrado dos Programas de ensino da UFRN. Natal, 25-27 de setembro, 2018.

Jacob, M.; Araújo, F. Capacity Building in Nutrition in the Context of Sustainable Food Systems. Ciência e Saúde 
Coletiva, 2020, ahead of print. Available at: < http://www. cienciaesaudecoletiva.com.br/artigos/desenvolvimento-de-competencias-para-nutricao-no-contexto-de-sistemas-alimentares-sustentaveis $/ 17192$ ? $\mathrm{id}=17192>$. Access on: jan. 2020.

Jesus, M.; Guerra, J. G.; Espindola, J. A.; Pacheco, S.; Borguini, R. G.; Godoy, R. L. O. et al. Teor de carotenoides de três variedades de batata-doce (Ipomoea batatas $L$.) cultivadas sob sistemas de produção orgânico e convencional. In: Anais do VI Congresso Latino-Americano de Agroecologia. Brasília, 12-15 de setembro, 2017. Available at: < https:// ainfo.cnptia.embrapa.br/digital/bitstream/item/184500/1/ Teor-de-carotenoides-de-tres-variedades-de-batata-doce. pdf $>$. Access on: dec. 2019.

Jia, S.; Shen, M.; Zhang, F.; Xi, J. Recent Advances in Momordica charantia: Functional Components and Biological Activities. Internacional Journal Molecular Sciences, 18(12), 2555, 2017. Available at: https://www.ncbi.nlm. nih.gov/pmc/articles/PMC5751158/

Kinupp, V. F.; Barros, I. B. I. Teores de proteína e minerals de espécies nativas, potenciais hortaliças e frutas. Ciencia e Tecnologia de Alimentos, 28(4), 846-57, 2008.

Kinupp, V. F.; Lorenzi, H. Plantas Alimentícias Não Convencionais (PANC) no Brasil. São Paulo: Editora Plantarum, 2014.

Lachat, C.; Raneri, J. E.; Smith, K. W., Kolsteren, P.; Damme, P. V.; Verzelen, K.; Penafiel, D.; Vanhove, W.; Kennedy, G.; Hunter, D.; Odhiambo, F. O.; Ntandou-Bouzitou, G.; De Baets, B.; Ratnasekera, D.; Ky, H. T.; Remans, R.; Termote, C. Dietary species richness as a measure of food biodiversity and nutritional quality of diets. PNAS, 115(1), 127-132, 2018. Available at: https://www.pnas.org/content/115/1/127

Lamarca, E. V.; Baptista, W.; Rodrigues, D. S.; Júnior, C. J. F. O. Contribuições do conhecimento local sobre o uso de Eugenia spp. em sistemas de policultivos e agroflorestas. Revista Brasileira de Agroecologia, 8(13), 119-30, 2013. Available at: http://revistas.aba-agroecologia.org.br/index. php/rbagroecologia/article/view/13256

Lang, T.; Barling, D. Nutrition and sustainability: An emerging food policy discourse. Proceedings of the Nutrition Society, 72(1), 1-12, 2013. Available at: https://www.cambridge. org/core/journals/proceedings-of-the-nutrition-society/ article/nutrition-and-sustainability-an-emerging-food-policy-discourse/FC6900B6815969B0ACC9E93FD571257A

Leone, A.; Spada, A.; Battezzati, A.; Schiraldi, A.; Aristil, J.; Bertoli, S. Moringa oleifera seeds and oil: Characteristics and uses for human health. International Journal of Molecular Sciences, 17(12), 1-14, 2016. Available at: https://www. ncbi.nlm.nih.gov/pmc/articles/PMC5187941/

Lévi-Strauss, C. Cultural diversity: the common heritage of humanity. In: Unesco. Echoing voices. Cultural diversity: a path to sustainable development. Paris: Unesco, 2011, p. 14, 15.

Louv, R. Last Child in the Woods. New York, NY: Algonquin Books, 2008.

Manek, R. V. et al. Physicochemical and binder properties of starch obtained from Cyperus esculentus. AAPS PharmSciTech, 13(2), 379-88, 2012. Available at: https://www. ncbi.nlm.nih.gov/pubmed/22350737

Martinelli, G.; Moraes, M. A. Livro Vermelho da Flora do Brasil. Rio de Janeiro: Jardim Botânico, 2013.

Mason, P.; Lang, T. Sustainable diets: How ecological nutrition can transform consumption and the food system. New York: Routledge, 2017.

Mercadante, A. Z.; Rodriguez-Amaya, D. B. Carotenoid Composition of a Leafy Vegetable in Relation to Some Agricultural Variables. Journal of Agricultural and Food Chemistry, 39(6), 1094-7, 1991. doi: 10.1021/jf00006a018

Morin, E. Introdução ao Pensamento Complexo. Porto Alegre: Sulina, 2015.

Mozaffarian, D.; Rosenberg, I.; Uauy, R. History of modern nutrition science-implications for current research, dietary guidelines, and food policy. British Medical Journal, 361, 1-6, 2018. Available at: $<$ https://www.bmj.com/content/361/ bmj.k2392

Myojin, C.; Enami, A.; Nagata, A.; Yamaguchi, T.; Takamura, H., Matoba, T. Changes in the radical-scavenging activity of bitter gourd (Momordica charantia L.) during freezing and frozen storage with or without blanching. Journal of Food Science, 73(7), C546-50, 2008. Available at: https:// www.ncbi.nlm.nih.gov/pubmed/18803700 
Narciso, G.; De Miranda, N.; Cabral, J.; Teixeira, N. Plantas Alimentícias Não Convencionais (PANC) na gastronomia: A Capeba (Pothomorphe umbellata) como base para elaboração de pratos. Revista Pensar Gastronomia, 1-25, 2017. Available at: http://revistapensar.com.br/gastronomia/ pasta_upload/artigos/a53.pdf

NEPA - Núcleo de Estudos e Pesquisas em Alimentação. Tabela Brasileira de Composição dos Alimentos (Taco). Campinas, SP: 2011.

Oliveira, D.; Wobeto, C.; Zanuzo, M. R.; Severgnini, C. Mineral composition and ascorbic acid content in four non-conventional leafy vegetables species. Horticultura Brasileira, 31(3), 472-5, 2013. doi: 10.1590/S010205362013000300021

Pascoe, J.; Wyatt-Smith, C. Curriculum literacies and the school garden. Literacy Learning: The Middle Years, 21(1), 34-47, 2013. Available at: https://research-repository. griffith.edu.au/bitstream/handle/10072/56446/90156_1. pdf? sequence $=1$

Passeggi, M. A experiência em formação. Educação, 34(2), 147-156, 2011. Available at: http://revistaseletronicas.pucrs. br/ojs/index.php/faced/article/view/8697

Ramachandran, C.; Peter, K. V.; Gopalakrishnan, P. K. Drumstick (Moringa oleifera): A multipurpose Indian vegetable. Economic Botany, 34(3), 276-83, 1980. Available at: https://www.jstor.org/stable/4254186

Ramos, F. P.; Santos, L. A. Da S.; Reis, A. B. C. Educação alimentar e nutricional em escolares: uma revisão de literatura. Cadernos de Saúde Pública, 29(11), 2147-2161, 2013. Available at: http://www.scielo.br/scielo.php?scrip$\mathrm{t}=$ sci_arttext\&pid=S0102-311X2013001100003

Rodrigues-Amaya, D. B. Tabela Brasileira de Composição de Carotenóides em Alimentos. Brasília: MMA, 2008.

Salatino, A.; Buckeridge, M. "Mas de que te serve saber botânica?" Estudos Avançados, 30(87), 177-196, 2016. doi: 10.1590/S0103-40142016.30870011

Santos, M. J. D.; Azevedo, T. A. O.; Freire, J. L. O.; Arnaud, D. K. L.; Reis, F. L. A. M. Horta Escolar Agroecológica: Incentivadora da Aprendizagem e de Mudanças de Hábitos Alimentares no Ensino Fundamental. Holos, 4, 278-90,
2014. Available at: http://www2.ifrn.edu.br/ojs/index.php/ HOLOS/article/view/1705

Sartori, S.; Donadio, L.; Martins, A; Moro, F. Uvaia. Jaboticabal: Funep, 2010.

DONADIO, L. C., MARTINS, A. B. G., MORO, F. V

Scrinis, G. On the Ideology of Nutritionism. Gastronomica, 8(1), 39-48, 2008. Available at: https://www.jstor.org/stable/ pdf/10.1525/gfc.2008.8.1.39.pdf

Shakerin, Z.; Esfandiari, E.; Ghanadian, M.; Razavi, S.; Alaei, H., Dashti, G. Therapeutic effects of Cyperus rotundus rhizome extract on memory impairment, neurogenesis and mitochondria in beta-amyloid rat model of Alzheimer's disease. Metabolic Brain Disease, 2019, ahead of print. Available at: https://www.ncbi.nlm.nih.gov/ pubmed/31734846

SiBBR - Sistema de Informação da Biodiversidade Brasileira. Uvaia, polpa, com casca, crua. Available at: $<$ https:// ferramentas.sibbr.gov.br>. Access on: dec. 2019.

Stadlmayr B.; Wijesinha-Bettoni, R.; Haytowitz, D.; Rittenschober, D.; Cunningham, J.; Sobolewsk, R.; Eisenwagen, S.; Baines, B.; Probst, Y.; Fitt, E.; Charrondiere, U.R.. FAO/ INFOODS Guidelines for food matching. Version 1.2. FAO: Rome, 2012.

Teixeira, E. Caracterização química e nutricional da folha de Moringa (Moringa oleifera Lam.) Araraquara, Tese (Doutorado em Ciências Farmaêuticas) - UNESP, 2012.

Uddin, M.; Juraimi, A. S.; Hossain, M. S.; Un, A.; Ali, M.;

Rahman, M. M. Purslane Weed (Portulaca oleracea): A Prospective Plant Source of Nutrition, Omega-3 Fatty Acid, and Antioxidant Attributes. The Scientific World Journal, 2014, p. 1-6, 2014. Available at: http://downloads.hindawi. com/journals/tswj/2014/951019.pdf

UN - United Nations. Nagoya Protocol on Access to Genetic Resources and the Fair and Equitable Sharing of Benefi ts Arising from their Utilization to the Convention on Biological Diversity. Montreal: UN, 2011.

UN - United Nations. The future we want. Rio+20 United Nations Conference on Sustainable Development. New York: UN, 2012. 
UN - United Nations. Transforming our world: the 2030 Agenda for Sustainable Development. New York: UN, 2015.

UN - United Nations. Decade of Action on Nutrition. New York: UN, 2016.

USDA - United States Department of Agriculture Agricultural Research Service. National Nutrient Database for Standard Reference Legacy Release. 2018. Available at: $<$ https://ndb.nal.usda.gov/ndb/>. Access on: dec. 2019.

Vega-Morales, T.; Mateos-Díaz, C.; Pérez-Machín, R.; Wiebe, J.; Gericke, N. P.; Alarcón, C.; López-Romero, J. $\mathrm{M}$. Chemical composition of industrially and laboratory processed Cyperus esculentus rhizomes. Food Chemistry, 2019, ahead of print. doi: 10.1016/j.foodchem.2019.05.170

Viana, M. M. S.; Carlos, L. A.; Silva, E. C.; Pereira, S. M. F.; Oliveira, D. B.; Assis, M. L. V. Phytochemical composition and antioxidant potential of unconventional vegetables. Horticultura Brasileira, 33(4), 504-9, 2015. doi: 10.1590/ S0102-053620150000400016

Wandersee, James; Schussler, E. Toward a Theory of Plant Blindness. Plant Science Bulletin, 47(1), 2-9, 2001. Avai- lable at: https://www.scienceopen.com/document?vid=2effbad5-04eb-450b-a058-3722d4473701

Williams, D.; Dixon, P. Impact of Garden-Based Learning on Academic Outcomes in Schools: Synthesis of Research Between 1990 and 2010. Review of Educational Research, 83(2), 211-235, 2013. Available at: https://journals.sagepub. com/doi/abs/10.3102/0034654313475824

Yli-Panula, E.; Jeronen, E.; Lemmetty, P.; Pauna, A. Teaching methods in biology promoting biodiversity education. Sustainability (Switzerland), 10(10), 1-18, 2018. Available at: https://ideas.repec.org/a/gam/jsusta/v10y2018i10p3812-d177296.html 